\title{
DETERMINING THE REPAIR RANKING OF EXISTING RC BRIDGES USING LEAST SQUARES TECHNIQUE ASSOCIATED WITH COMPARISON MATRIX METHOD
}

\author{
Ming-Te Liang \\ Professor, Department of Civil Engineering, China Institute of Technology, Taipei, Taiwan 11571, R.O.C., \\ mtliang@cc.chit.edu.tw \\ Chin-Ming Lin \\ Graduate Student, Department of Harbor and River Engineering, National Taiwan Ocean University, Keelung, Taiwan \\ 20224, R.O.C. \\ Wen-Hu Tsao \\ Associate Professor, Department of Civil Engineering, China Institute of Technology, Taipei, Taiwan 11571, R.O.C. \\ Chi-Jang Yeh \\ Manager, Join Engineering Consultant, Taipei, Taiwan 115, R.O.C
}

Follow this and additional works at: https://jmstt.ntou.edu.tw/journal

Part of the Civil and Environmental Engineering Commons

\section{Recommended Citation}

Liang, Ming-Te; Lin, Chin-Ming; Tsao, Wen-Hu; and Yeh, Chi-Jang (2006) "DETERMINING THE REPAIR RANKING OF EXISTING RC BRIDGES USING LEAST SQUARES TECHNIQUE ASSOCIATED WITH COMPARISON MATRIX METHOD," Journal of Marine Science and Technology. Vol. 14: Iss. 4, Article 17.

DOI: 10.51400/2709-6998.2096

Available at: https://jmstt.ntou.edu.tw/journal/vol14/iss4/17

This Research Article is brought to you for free and open access by Journal of Marine Science and Technology. It has been accepted for inclusion in Journal of Marine Science and Technology by an authorized editor of Journal of Marine Science and Technology. 
DETERMINING THE REPAIR RANKING OF EXISTING RC BRIDGES USING LEAST SQUARES TECHNIQUE ASSOCIATED WITH COMPARISON MATRIX METHOD

Acknowledgements

The authors would like to thank the Join Engineering Consultant for financial support for this study. 


\title{
DETERMINING THE REPAIR RANKING OF EXISTING RC BRIDGES USING LEAST SQUARES TECHNIQUE ASSOCIATED WITH COMPARISON MATRIX METHOD
}

\author{
Ming-Te Liang*, Chin-Ming Lin**, Wen-Hu Tsao*** and Chi-Jang Yeh****
}

Key words: entropy, priority index, Lagrange's function, possibility, membership grade.

\section{ABSTRACT}

The principal objective of this paper is employed the least squares technique associated with comparison matrix method to determine the repair ranking of existing reinforced concrete (RC) bridges with bestridden or non-bestridden river. Six existing RC bridges in Taiwan are given as an illustrative example. For verifying the feasibility and reliability of the proposed method, the D (Degree) E (Extent) R (Relevancy) evaluation method, which is only considered the $\mathrm{RC}$ bridges built on river bed and is now widely used to evaluate the damage grade for existing RC bridges in Taiwan, is also adopted to assessing the same six existing RC bridges. The predicted results obtained from both the proposed and DER evaluation methods have the same repair ranking. The present study provides the weight for each item of RC bridge with bestridden and non-bestridden rivers in the DER evaluation method, respectively. The results in this study could be used as engineering decision-making for the repair, strengthening or demolition rankings for existing RC bridges.

\section{INTRODUCTION}

Currently, there are many methods for evaluating the damage grade of existing reinforced concrete (RC) bridges. Nevertheless, the structural system of assessment method is formed by two parts: One is calculation principle such as synthetically weighting method [12], linear distribution method [16], TOPSIS (Technique for Order Preference by Similarity to Ideal Solution] [2] and weight average planning method [21]. The other one is weight distribution such as eigenvector method

Paper Submitted 01/20/06, Accepted 03/24/06. Author for Correspondence: Ming-Te Liang. E-mail: mtliang@cc.chit.edu.tw.

*Professor, Department of Civil Engineering, China Institute of Technology, Taipei, Taiwan 11571, R.O.C.

**Graduate Student, Department of Harbor and River Engineering, National Taiwan Ocean University, Keelung, Taiwan 20224, R.O.C.

***Associate Professor, Department of Civil Engineering, China Institute of Technology, Taipei, Taiwan 11571, R.O.C.

****Manager, Join Engineering Consultant, Taipei, Taiwan 115, R.O.C.
[17], minimum square sum method [6], Delphi's method [8] and circulation comparison evaluation method [15]. The evaluation system composed by both of them has the large influence to the last assessed result. In particular, the influence of weight distribution is very obvious. Most evaluation methods are necessarily recognized by expert. This belongs to subjective weight. The subjective weight is usually simple to be performed. However, it is very easy to influence by the experience, knowledge and ability of the expert. For instance, if the expert leans on some bridge member weight or does not completely understand the evaluation bridge, then the evaluation result is not reliable. On the other hand, there is objectivity in weight. This kind of weight is occurred from the bridge member subjected to damage. Simply speaking, if any one member of bridge is suffered severe damage then this member is needed to be more weight. Although the actual condition of evaluated bridge is not influenced by the expert, that is, the objective weight is neglected by the degree of leaning on the expert, the evaluated result is still not correct.

Saaty [18] provides a theory of analytical hierarchies for quantitative modeling unstructured decision problems. These unstructured problems are illustrated through application of forward-backward planning, a two-point boundary value problem. Brown and Yao [1] applied the fuzzy set theory first to consider the fuzzification of objective information where cylinder test results on concrete are used as a basis for the evaluation of the actual strength in a structural member. They also concerned an engineer's assessment of the damage to a structure and subsequent repairs. In the case of weighting sum method of binomial coefficient for treating multiple objective decision-making problem, Cheng [4] provided the weight through scoring to major and minor characteristics for the complicate target weight. Jenn [9] adopted the valuable weight of pair comparison in the weight method for multiple objective decision-making. This means passed the subjective value to judge the weight and organized the weight 
together to respond any objective with relative importance. Chou and Yuan [5] presented an algorithm to compute the posterior probability based on visual inspection of structural components by incorporating fuzzy-set theory into Bayes' theory. In the study of compose bestowal method of weight coefficient in multiple objective, Wei and Feng [23] determined the weight by the method of mathematics and statistics for following the scientific reasonality. Zhao and Chen [25] used fuzzy inference system to construct the framework of a fuzzy expert system for diagnosing bridge damages and for providing bridge designers with valuable information about the impact of design parameter on bridge deterioration. Liang et al. [13] employed comparison matrix method to determine the repair ranking for existing RC bridges with bestridden river. To date, however, no studies have attempted to determining the repair ranking for existing $\mathrm{RC}$ bridges without bestridden river. This is a notable shortcoming, because the use of fuzzy set theory in previous studies may extend to investigate the existing $\mathrm{RC}$ bridges without bestridden river.

The main propose of this paper is to provide a determining weight method that simulate the expert subjective and to emerge from the actual bridge objective for having reasonable weight. Moreover, the combination of the least squares technique with comparison matrix method is used to evaluate the repair ranking of existing $\mathrm{RC}$ bridges with bestridden or non-bestridden river. The present study results may be used as critical engineering decision-making for the repair, strengthening or demolition rankings for existing $\mathrm{RC}$ bridges.

\section{WEIGHT SOLUTION OF LEAST SQUARES TECHNIQUE}

\section{Subject to optimization specification}

\section{(1) Subject to identity problem (Lagrange's function)}

Basically, the optimization problems of repair or strengthening engineering of existing RC bridges have many limitations to some variables. The appearance of limitation decreases the available region of searching optimization point. The Lagrange function is only provided a set of necessary condition for justifying the candidate optimization point of finite identity optimization problem. The concept of solving these problems is to apply the undetermined parameters of Lagrange's multipliers for transferring the finite problem to the equivalent infinite problem.

Consider the function $f$ of minimum extreme value problem subjected to an equal limitation $n$ variables

$$
\begin{aligned}
& \min f\left(x_{1}, x_{2}, \ldots, x_{n}\right) \\
& \text { s.t. } h_{1}\left(x_{1}, x_{2}, \ldots, x_{n}\right)=0
\end{aligned}
$$

where s.t means subject to.

Using the concept of Lagrange's multipliers, Eq.(1) can be written as

$$
\min L(x, \lambda)=f(x)-\lambda h_{1}(x)
$$

where the infinite function $L(x, \lambda)$ is called Lagrange's function and $\lambda$ is an undetermined constant and is referred to as Lagrange's multiplier.

The value of $\lambda$ is free of limition of positive or negative. Liu [14] used the least squares technique to establish an optimal model. This can be expressed as

$$
\begin{aligned}
& \min H(w)=\sum_{i=1}^{n} \sum_{j=1}^{m}\left[\left(w_{j}-u_{j}\right) a_{i j}\right]^{2} \\
& +\sum_{i=1}^{n} \sum_{j=1}^{m}\left[\left(w_{j}-v_{j}\right) a_{i j}\right]^{2} \\
& \text { s.t. } \sum_{j=1}^{m} w_{j}=1 \\
& w_{j} \geq 0, j=1,2, \ldots, m
\end{aligned}
$$

where $H(w)$ is the decision-making value, $w_{j}$ is the value of assessment item, $a_{i j}$ is the membership grade of decision-making, $u_{j}$ and $v_{j}$ are the subjective and objective weight of assessment item, respectively.

Using the concept of Lagrange's multipliers, Eq. (3) is changed as the minimum extreme value problem of the equivalent infinite problem and expressed as

$$
\begin{aligned}
\min L(w, \lambda) & =\sum_{i=1}^{n} \sum_{j=1}^{m}\left[\left(w_{j}-u_{j}\right) a_{i j}\right]^{2} \\
& +\sum_{i=1}^{n} \sum_{j=1}^{m}\left[\left(w_{j}-v_{j}\right) a_{i j}\right]^{2}-2 \lambda f(w)
\end{aligned}
$$

To solving the coefficient problem of the function, one may assume

$$
f(w)=2\left(\sum_{j=1}^{m} w_{j}-1\right)
$$

For having both the leaning on bridge assessment item and the enforcing reduction subjective random, one may reach the union of subject and object for giving weight to bridge assessment item. Substituting Eq.(5) into Eq. (4), one has 


$$
\begin{aligned}
\min L(w, \lambda) & =\sum_{i=1}^{n} \sum_{j=1}^{m}\left[\left(w_{j}-u_{j}\right) a_{i j}\right]^{2} \\
& +\sum_{i=1}^{n} \sum_{j=1}^{m}\left[\left(w_{j}-v_{j}\right) a_{i j}\right]^{2} \\
& -4 \lambda\left(\sum_{j=1}^{m} w_{j}-1\right)
\end{aligned}
$$

In order to have the zero value of gradient of $L(w, \lambda)$ with respect to $\mathrm{w}$ and $\lambda$, one orders $\frac{\partial L}{\partial w_{j}}=0$ and $\frac{\partial L}{\partial \lambda}=0$ and has, respectively,

$$
2 \sum_{i=1}^{n}\left(w_{j}-u_{j}\right) a_{i j}^{2}+2 \sum_{i=1}^{n}\left(w_{j}-v_{j}\right) a_{i j}^{2}-4 \lambda=0
$$

and

$$
\sum_{j=1}^{m} w_{j}-1=0
$$

Equation (7) is changed as

$$
w_{j} \sum_{i=1}^{n} a_{i j}^{2}-\lambda=\frac{1}{2}\left(u_{j}+v_{j}\right) \sum_{i=1}^{n} a_{i j}^{2}
$$

From Eq. (8), one obtains $\sum_{j=1}^{m} w_{j}=1$ which is satisfied Eq. (3). Equation (9) can be written in terms of matrix equation as

$$
\left[\begin{array}{cc}
B_{m m} & e_{m 1} \\
e_{1 m}^{T} & 0
\end{array}\right]\left[\begin{array}{c}
W_{m 1} \\
-\lambda
\end{array}\right]=\left[\begin{array}{c}
C_{m 1} \\
1
\end{array}\right]
$$

where

$$
\begin{aligned}
B_{m m}= & \operatorname{diag}\left|\sum_{i=1}^{n} a_{i 1}^{2}, \sum_{i=1}^{n} a_{i 2}^{2}, \cdots, \sum_{i=1}^{n} a_{i m}^{2}\right| \\
e_{m 1}= & (1,1, \ldots, 1)^{T} \\
C_{m 1}= & \mid \sum_{i=1}^{n} \frac{1}{2}\left(u_{1}+v_{1}\right) a_{i 1}^{2}, \sum_{i=1}^{n} \frac{1}{2}\left(u_{2}+v_{2}\right) a_{i 2}^{2}, \cdots, \\
& \left.\sum_{i=1}^{n} \frac{1}{2}\left(u_{m}+v_{m}\right) a_{i m}^{2}\right|^{T}
\end{aligned}
$$

in which $\mathrm{T}$ is the transpose of matrix.

The exact solution of Eq.(10) is

$$
\begin{aligned}
w & =\left(w_{1}, w_{2}, \ldots, w_{m}\right)^{T} \\
& =B_{m m}^{-1}\left|C_{m 1}+\frac{1-e_{1 m}^{T} B_{m m}^{-1} C_{m 1}}{e_{1 m}^{T} B_{m m}^{-1} C_{m 1}} e_{m 1}\right|
\end{aligned}
$$

\section{(2) Weighting least squares technique}

The model of weighting least squares technique is defined as

$$
\begin{aligned}
& \min H(w)=\sum_{i=1}^{n} \sum_{j=1}^{m} \alpha\left[\left(w_{j}-u_{j}\right) a_{i j}\right]^{2} \\
& +\sum_{i=1}^{n} \sum_{j=1}^{m} \beta\left[\left(w_{j}-v_{j}\right) a_{i j}\right]^{2} \\
& \text { s.t. } \sum_{j=1}^{m} w_{j}=1 \\
& w_{j} \geq 0, j=1,2, \ldots, m
\end{aligned}
$$

where $\alpha$ and $\beta$ are the importance of the subjective and objective weight, respectively. It is needed to point out that $\alpha+\beta=1, \alpha>0, \beta>0$.

If consider the Eq. (12) as a Lagrange function, then one has

$$
\begin{aligned}
\min L(w, \lambda) & =\sum_{i=1}^{n} \sum_{j=1}^{m} \alpha\left[\left(w_{j}-u_{j}\right) a_{i j}\right]^{2} \\
& +\sum_{i=1}^{n} \sum_{j=1}^{m} \beta\left[\left(w_{j}-v_{j}\right) a_{i j}\right]^{2}-\lambda f(w)
\end{aligned}
$$

The substitution of Eq. (5) into Eq. (13) yields

$$
\begin{aligned}
\min L(w, \lambda) & =\sum_{i=1}^{n} \sum_{j=1}^{m} \alpha\left[\left(w_{j}-u_{j}\right) a_{i j}\right]^{2} \\
& +\sum_{i=1}^{n} \sum_{j=1}^{m} \beta\left[\left(w_{j}-v_{j}\right) a_{i j}\right]^{2} \\
& -2 \lambda\left(\sum_{j=1}^{m} w_{j}-1\right)
\end{aligned}
$$

Taking partial derivative to $w_{j}$ for Eq. (14), one gets

$$
\sum_{i=1}^{n}\left[\alpha \sum_{j=1}^{m}\left(w_{j}-u_{j}\right)+\beta \sum_{j=1}^{m}\left(w_{j}-v_{j}\right)\right] a_{i j}^{2}-\lambda=0
$$

Finding the sum for both sides to $\mathrm{j}$ to Eq. (15), one obtains

$$
\begin{gathered}
\sum_{j=1}^{m}\left[\alpha w_{j}-\alpha u_{j}+\beta w_{j}-\beta v_{j}\right]=\sum_{j=1}^{m} \frac{\lambda}{\sum_{i=1}^{n} a_{i j}^{2}} \\
\sum_{j=1}^{m} w_{j}(\alpha+\beta)-\alpha u_{j}-\beta v_{j}=\sum_{j=1}^{m} \frac{\lambda}{\sum_{i=1}^{n} a_{i j}^{2}}
\end{gathered}
$$


Since $\alpha+\beta=1, \sum_{j=1}^{m} w_{j}=1, \sum_{j=1}^{m} u_{j}=1$, and $\sum_{j=1}^{m} v_{j}=1$, one knows that the left side of Eq. (17) is zero. Hence, one obtains $\sum_{j=1}^{m} \frac{\lambda}{\sum_{i=1}^{n} a_{i j}^{2}}=0$. Because $a_{i j}^{2} \neq 0$, one has $\lambda=0$. If $\lambda=0$, then Eq. (13) is satisfied the Eq. (12). Moreover, from Eq. (17), one has

$$
w_{j}(\alpha+\beta)-\alpha u_{j}-\beta v_{j}=0
$$

Putting $(\alpha+\beta)=1$ into Eq. (18), one has

$$
w_{j}=\alpha u_{j}+\beta v_{j}
$$

where $w_{j}$ is the weight value of weighting least squares technique, $\alpha$ and $\beta$ herein represent the importance of the interval number complementary judgment matrix method and the entropy information subjectivity method, respectively. Furthermore, $w=\left(w_{1}, w_{2}, \ldots w_{n}\right)^{T}$ is the weight vector of assessment items.

\section{Subjective weight method}

\section{(1) Establish decision-making matrix}

Assume that there are $n$ numbers of existing RC bridges for determining the repair ranking and forming the decision-making set $D=\left\{d_{1}, d_{2}, \ldots, d_{n}\right\}$. Suppose each RC bridge has 21 assessment items and forms assessment items set $B=\left\{b_{1}, b_{2}, \ldots, b_{21}\right\}$.

The assessment of $\mathrm{B}$ to $\mathrm{D}$ can be established decision-making matrix

$$
\begin{aligned}
& X=\left[\begin{array}{ccc}
x_{11} & \cdots & x_{1 m} \\
\vdots & \ddots & \vdots \\
x_{211} & \cdots & x_{21 m}
\end{array}\right]=\left[x_{i j}\right] \\
& \mathrm{i}=1,2, \ldots, 21 ; \mathrm{j}=1,2, \ldots, \mathrm{n}
\end{aligned}
$$

(2) Relative membership grade

The relative membership grade can be defined as

$$
r_{i j}=\left\{\begin{array}{l}
0 \quad, x_{i j} \leq y_{i c} \\
\frac{x_{i j}-y_{i c}}{y_{i 1}-y_{i c}}, y_{i 1}>x_{i j}>y_{i c} \\
1 \quad, x_{i j} \geq y_{i 1}
\end{array}\right.
$$

where $y_{i 1}$ and $y_{i c}$ are the first grade " 1 " and the c class standard value of assessment item i, respectively.

Chen [3] divided c class into $\mathrm{c}=2$, i.e., $\mathrm{c}=1$ (optimum) and $c=2$ (pessimum). Then, $\operatorname{Eq}(21)$ is changed as

$$
r_{i j}=\frac{x_{i j}-y_{i 2}}{y_{i 1}-y_{i 2}}
$$

For fitting the requirement of evaluation, Eq.(22) has two kinds of calculation models described as follows:

\section{A. Effect type}

With regard to effect type index, i.e., the larger attribution of assessment item is, the better service state of assessment item has, substituting $\mathrm{c}=1, y_{i 1}=x_{i \max }$ and $\mathrm{c}=2, y_{i 2}=0$ into Eq.(22), one gets the relative membership grade of class

$$
r_{i j}=\frac{x_{i j}}{x_{i \max }}
$$

\section{B. Cost type}

In relation to cost type index, i.e., the smaller attribution of assessment item is, the better of assessment item has, substituting $\mathrm{c}=1, y_{i 1}=0$ and $\mathrm{c}=2, y_{i 2}=$ $x_{i \text { max }}$ into Eq.(22), one obtains the relative membership grade of class

$$
r_{i j}=1-\frac{x_{i j}}{x_{i \max }}
$$

(3) Transform the decision-making matrix into the relative membership grade matrix

Let the value of decision-making locate between 0 and 1 through the formulas of relative membership grade for eliminating the influence of unrequired physical unit effect in evaluation system. The relative membership grade matrix is

$$
\begin{aligned}
& R=\left[\begin{array}{ccc}
r_{11} & \cdots & r_{1 n} \\
\vdots & \ddots & \vdots \\
r_{211} & \cdots & r_{21 n}
\end{array}\right]=\left[r_{i j}\right] \\
& \mathrm{i}=1,2, \ldots, 21 ; \mathrm{j}=1,2, \ldots, \mathrm{n}
\end{aligned}
$$

\section{(4) Weight planning}

Define the reliability when $a \geq b$

$$
p^{*}(a \geq b)=\frac{\max \left(0, L(a)+L(b)-\max \left(0, b^{+}-a^{-}\right)\right)}{L(a)+L(b)}
$$


where $a=\left[a^{-}, a^{+}\right], b=\left[b^{-}, b^{+}\right], L(a)=a^{+}-a^{-}$and $L(b)$ $=b^{+}-b^{-}$.

The properties of $p^{*}(a \geq b)$ are

(1) if $p^{*}(a \geq b)=p^{*}(b \geq a)$ then $p^{*}(a \geq b)=p^{*}(b \geq a)$ $=0.5$

(2) $p^{*}(a \geq b)+p^{*}(b \geq a)=1$

(3) if $a^{+} \leq b^{-}$then $p^{*}(a \geq b)=0$

(4) if $a^{-} \geq b^{-}$then $p^{*}(a \geq b)=1$

(5) regarding three interval numbers $\mathrm{a}, \mathrm{b}$ and $\mathrm{c}$, if $a \geq b$ then $p^{*}(a \geq c) \geq p^{*}(b \geq c)$.

After the judgment using Table 1 [19], one can build interval number complementary judgment matrix

$$
A^{*}=\left(a_{i j}\right)_{n \times m}
$$

where $a_{i j}=\left[a_{i j}, a_{i j}^{+}\right], a_{i j}+a_{i j}^{+}=a_{i j}^{+}+a_{i j}, a_{i i}=0.5$, and $0<a_{i j}<1, i, j=1,2, \ldots, 21$,

$a=\left[a^{-}, a^{+}\right]=\left\{t \mid 0<a^{-} \leq \mathrm{t} \leq a^{+}\right\}$is called an interval number. Performing calculation to the interval number complementary judgment matrix, the interval number weight vector $w^{*}$ can be found as

$$
\begin{aligned}
w_{i}^{*} & =\frac{\sum_{j=1}^{n} a_{i j}}{\sum_{i=1}^{n} \sum_{j=1}^{n} a_{i j}}=\frac{\sum_{j=1}^{n}\left[a_{i j}^{-}, a_{i j}^{+}\right]}{\sum_{i=1}^{n} \sum_{j=1}^{n}\left[a_{i j}^{-}, a_{i j}^{+}\right]} \\
& =\frac{\left|\sum_{j=1}^{n} a_{i j}^{-}, \sum_{j=1}^{n} a_{i j}^{+}\right|}{\left|\sum_{i=1}^{n} \sum_{j=1}^{n} a_{i j}^{-}, \sum_{i=1}^{n} \sum_{j=1}^{n} a_{i j}^{+}\right|} \\
& =\left|\frac{\sum_{j=1}^{n} a_{\overline{i j}}^{n}}{\sum_{i=1}^{n} \sum_{j=1}^{n} a_{i j}^{+}}, \frac{\sum_{j=1}^{n} a_{i j}^{+}}{\sum_{i=1}^{n} \sum_{j=1}^{n} a_{\overline{i j}}^{-}}\right|, i \in N
\end{aligned}
$$

Equation (28) represents the interval range of weight. Carrying out the pair comparison of assessment items and using Eq.(26), one establishes the possibility matrix

$$
P^{*}=\left[\begin{array}{cccc}
P_{11}^{*} & P_{12}^{*} & \cdots & P_{1 n}^{*} \\
P_{21}^{*} & P_{22}^{*} & \cdots & P_{2 n}^{*} \\
\vdots & \vdots & \ddots & \vdots \\
P_{n 1}^{*} & P_{n 2}^{*} & \cdots & P_{n m}^{*}
\end{array}\right]=\left[p_{i j}^{*}\right]
$$

$\mathrm{Xu}$ and Sun [24] provided a simple calculation weight formula for the possibility matrix
Table 1. Mark significance

\begin{tabular}{ll}
\hline Mark & \multicolumn{1}{c}{ Significance } \\
\hline 0.1 & Extreme importance of $\mathrm{b}$ member larger than a member \\
0.138 & Severe importance of $\mathrm{b}$ member larger than a member \\
0.325 & Evident importance of $\mathrm{b}$ member larger than a member \\
0.439 & Slightly importance of $\mathrm{b}$ member larger than a member \\
0.5 & a and $\mathrm{b}$ member have the same importance \\
0.561 & Slightly importance of a member larger than $\mathrm{b}$ member \\
0.675 & Evident importance of a member larger than $\mathrm{b}$ member \\
0.862 & Severe importance of a member larger than $\mathrm{b}$ member \\
0.9 & Extreme importance of a member larger than $\mathrm{b}$ member \\
\hline
\end{tabular}

$$
w_{i}=\frac{\sum_{j=1}^{n} p_{i j}^{*}+\frac{n}{2}-1}{n(n-1)}
$$

where $\mathrm{n}$ is the member number of assessment item. One may adopt Eq.(30) for finding the weight vector of possibility matrix.

\section{Subjective weight method}

Wang et al. [22] pointed out that entropy is a measurement for the system state (random event) uncertainty or information. The premise of measurement information in information theory is acquired information without uncertainty. Accordingly, the magnitude of information amount can be used to express the magnitude of the eliminated uncertainty.

Assume that there are $n$ numbers of exiting $\mathrm{RC}$ bridges for determining repair ranking and recording it as $A=\left\{A_{1}, A_{2}, \ldots, A_{n}\right\}$. Each bridge has m numbers assessment items, i.e., $C=\left\{C_{1}, C_{2}, \ldots, C_{m}\right\}$. If the attribution of bridge $A_{i}, \mathrm{i}=1,2, \ldots, \mathrm{n}$, to assessment item, $C_{j}=1,2, \ldots, \mathrm{m}$, is $r_{i j}$, then the decision- making matrix is

$$
R=\left[\begin{array}{ccccc}
r_{11} & r_{12} & \cdots & \cdots & r_{1 m} \\
r_{21} & r_{22} & \cdots & \cdots & r_{2 m} \\
\vdots & \vdots & \ddots & & \vdots \\
\vdots & \vdots & & \ddots & \vdots \\
r_{n 1} & r_{n 2} & \cdots & \cdots & r_{n m}
\end{array}\right]=\left[r_{i j}\right]_{n \times m}
$$

For the sake of eliminating the different influences of physical units for m numbers of assessment items, one needs to normalize the membership function of the assessment items of quantitative index.

If the smaller attribution of assessment item is, the better service state of assessment item has, then the optimum membership function is 


$$
a_{i j}=\frac{\max \left(r_{i j}\right)-r_{i j}}{\max \left(r_{i j}\right)-\min \left(r_{i j}\right)}
$$

whereis $a_{i j}$ the optimum membership function of the jth assessment item in the $i$-th alternative, $r_{i j}$ is the attribution value of the $\mathrm{j}$-th assessment item in the $\mathrm{i}$-th alternative, and max $\left(r_{i j}\right)$ and $\min \left(r_{i j}\right)$ are the maximum and minimum values of $r_{i j}$, respectively.

If the larger attribution of assessment item is, the better service state of assessment item has, then the optimal membership function is

$$
a_{i j}=\frac{r_{i j}-\min \left(r_{i j}\right)}{\max \left(r_{i j}\right)-\min \left(r_{i j}\right)}
$$

Thus, one gains the normalization decision-making matrix

$$
A=\left[\begin{array}{ccccc}
a_{11} & a_{12} & \cdots & \cdots & a_{1 m} \\
a_{21} & a_{22} & \cdots & \cdots & a_{2 m} \\
\vdots & \vdots & \ddots & & \vdots \\
\vdots & \vdots & & \ddots & \vdots \\
a_{n 1} & a_{n 2} & \cdots & \cdots & a_{n m}
\end{array}\right]=\left[a_{i j}\right]_{n \times m}
$$

Let

$$
P_{i j}=\frac{a_{i j}}{\sum_{i=1}^{n} a_{i j}}
$$

then the output information entropy of assessment item is

$$
E_{j}=-\frac{1}{(\ln n)} \sum_{i=1}^{n} P_{i j} \times \ln P_{i j}
$$

where $\ln =\log _{\mathrm{e}}$.

If $P_{i j}=0$ then $P_{i j} \times \ln P_{i j}=0$. If under the same index the difference among different optimum membership function of each bridge, $a_{i j}$, is large then this index is responded the more important in evaluation. That is, the index transfer the more information to bridge expert. This can be represented by the objective weight as

$$
v_{j}=\frac{1-E_{j}}{\sum_{k=1}^{m}\left(1-E_{k}\right)}
$$

Thus, $v_{j}=\left(v_{1}, v_{2}, \ldots, v_{n}\right)^{T}$ is the weight vector of assessment item $C_{j}$, where $\sum_{i=1}^{n} v_{i}=1, v_{i}>0$.

\section{ILLUSTRATIVE EXAMPLE}

Six existing RC bridges (the Guang-hua and new Hwan-nan bridges [11], the old Hwan-nan, Ay-gwo, Tzyh-chyang, and Huey-tong bridges [20]) in Taiwan are adopted for determining the bridge member importance ranking and bridge system repair ranking. It is worthy to point out that the Tzyh-chyang and Huey-tong bridges are built on river bed while the Guang-hua, Aygwo, new and old Hwan-nan bridges are not built on river bed. The composite member DER values of the Guang-hua bridge is listed in Table 2 [10]. The composite member DER values [7] of the other bridges are not indicated due to the limitation of paper length by the journal. Based on the data of composite member DER values of six existing RC bridges, the decision-making matrix $R=\left[r_{1}, r_{2}\right]$, where $r_{1}=$ general assessment items $=D \times E \times R$ and $r_{2}=$ detail assessment items $=D \times E \times R$, is shown in Table 3. For eliminating the different influences of physical units of 21 assessment items, one needs to normalize the decision-making matrix. The optimal membership function represented in Eq.(33) is followed the evaluated requirement. Thus, one obtains the membership grade of assessment items decisionmaking matrix as listed in Table 4. For not losing the generality of weight, one adopts the interval number complementary judgment matrix method and the entropy information weighting method for the subjective and objective weights, respectively.

\section{Bridge with bestridden river}

\section{(1) Subjective weight method}

Using Table 1 [19] and Eq. (27), one obtains the interval number complementary judgment matrix of assessment items as indicated in Table 5. Through Eq. (28), the weight interval of assessment items are calculated as displayed in Table 6. Employing Eq. (29), one establishes the possibility matrix as shown in Table 7. Let the raw sum of possibility matrix be normalized then one obtains the subjective weight of assessment items. That is the weight of general assessment items

$$
\begin{aligned}
& u_{1}= {\left[\begin{array}{lllll}
0.0715 & 0.0569 & 0.0878 & 0.0708 & 0.1498 \\
0.1346 & 0.1139 & 0.0708 & 0.0894 & 0.0528 \\
& 0.0710 & 0.0307
\end{array}\right]^{\mathrm{T}} } \\
&
\end{aligned}
$$

the weight of detail assessment items

$$
\begin{aligned}
& u_{2}=\left[\begin{array}{lllll}
0.0933 & 0.1539 & 0.1498 & 0.0562 & 0.0562
\end{array}\right. \\
& \left.\begin{array}{llll}
0.0935 & 0.1539 & 0.0935 & 0.1498
\end{array}\right]^{\mathrm{T}}
\end{aligned}
$$


Table 2. Each composite member DER value for the Guang-hua bridge in Taiwan

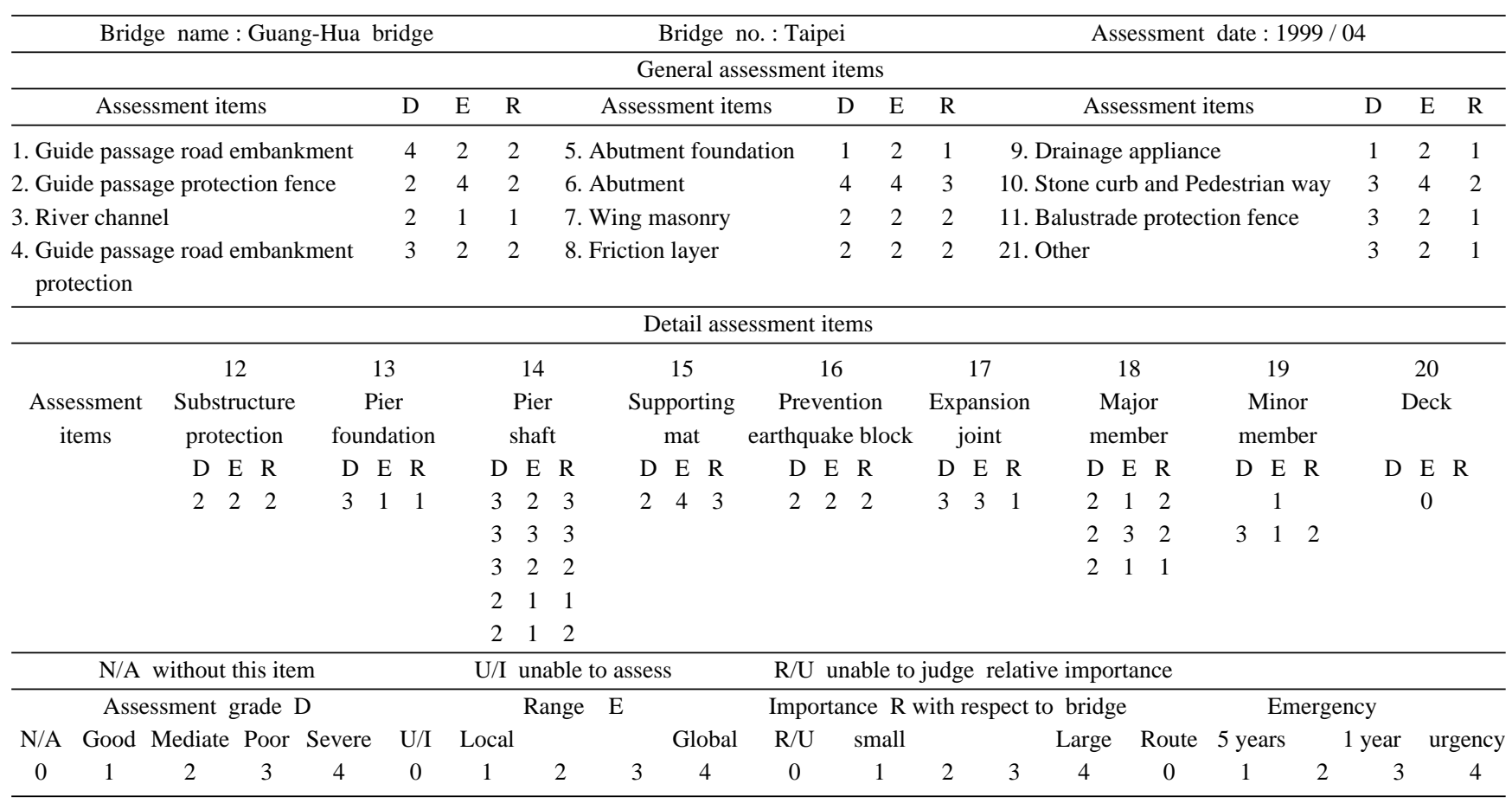

Table 3. Assessment items decision making matrix $\mathbf{R}$

\begin{tabular}{|c|c|c|c|c|c|c|c|c|c|c|c|c|}
\hline \multicolumn{13}{|c|}{ General assessment items $\left[r_{1}\right]$} \\
\hline$\left[r_{1}\right]$ & $\begin{array}{c}\text { Guide } \\
\text { passage } \\
\text { road } \\
\text { embankment }\end{array}$ & $\begin{array}{c}\text { Guide } \\
\text { passage } \\
\text { protection } \\
\text { fence } \\
\end{array}$ & $\begin{array}{c}\text { River } \\
\text { channel }\end{array}$ & $\begin{array}{c}\text { Guide } \\
\text { passage road } \\
\text { embankment } \\
\text { protection }\end{array}$ & $\begin{array}{l}\text { Abutment } \\
\text { foundation }\end{array}$ & Abutment & $\begin{array}{c}\text { Wing } \\
\text { masonry }\end{array}$ & $\begin{array}{c}\text { Friction } \\
\text { layer }\end{array}$ & $\begin{array}{l}\text { Drainage } \\
\text { appliance }\end{array}$ & $\begin{array}{l}\text { Stone curb } \\
\text { and } \\
\text { Pedestrian } \\
\text { way } \\
\end{array}$ & $\begin{array}{c}\text { Balustrade } \\
\text { protection } \\
\text { fence }\end{array}$ & Other \\
\hline $\begin{array}{l}\text { Guang-hua } \\
\text { bridge }\end{array}$ & 16 & 16 & 2 & 12 & 2 & 48 & 8 & 8 & 2 & 24 & 6 & 6 \\
\hline $\begin{array}{l}\text { new Hwan-nan } \\
\text { bridge }\end{array}$ & 8 & 8 & 8 & 8 & 8 & 24 & 6 & 2 & 12 & 18 & 2 & 2 \\
\hline $\begin{array}{l}\text { old Hwan-nan } \\
\text { bridge }\end{array}$ & 18 & 18 & 9 & 12 & 9 & 48 & 6 & 12 & 8 & 18 & 12 & 12 \\
\hline Ay-gwo bridge & 16 & 16 & 8 & 18 & 8 & 8 & 12 & 12 & 6 & 36 & 12 & 2 \\
\hline $\begin{array}{l}\text { Tzyh-chyang } \\
\text { bridge }\end{array}$ & 16 & 16 & 12 & 18 & 12 & 48 & 12 & 6 & 12 & 18 & 4 & 12 \\
\hline $\begin{array}{l}\text { Huey-tong } \\
\text { bridge }\end{array}$ & 18 & 18 & 9 & 12 & 9 & 48 & 2 & 12 & 6 & 6 & 12 & 6 \\
\hline Detail assessment & items $\left[r_{2}\right]$ & & & & & & & & & & & \\
\hline$\left[r_{2}\right]$ & & $\begin{array}{l}\text { ubstructure } \\
\text { protection }\end{array}$ & $\begin{array}{c}\text { Pier } \\
\text { foundation }\end{array}$ & $\begin{array}{l}\text { Pier } \\
\text { shaft }\end{array}$ & $\begin{array}{r}\text { Suppo } \\
\mathrm{m}\end{array}$ & $\begin{array}{l}\text { rting } \\
\text { at }\end{array}$ & $\begin{array}{l}\text { Prevention } \\
\text { earthquake } \\
\text { block }\end{array}$ & $\begin{array}{r}\text { Exp } \\
\text { jc }\end{array}$ & $\begin{array}{l}\text { nsion } \\
\text { int }\end{array}$ & $\begin{array}{l}\text { Major } \\
\text { member }\end{array}$ & $\begin{array}{l}\text { Minor } \\
\text { member }\end{array}$ & Deck \\
\hline Guang-hua brid & & 8 & 3 & 27 & 2 & 4 & 8 & & 9 & 12 & 6 & 0 \\
\hline new Hwan-nan & bridge & 2 & 3 & 4 & & 0 & 8 & & 8 & 12 & 12 & 12 \\
\hline old Hwan-nan b & ridge & 6 & 2 & 64 & 4 & 8 & 4 & & 7 & 64 & 64 & 27 \\
\hline Ay-gwo bridge & & 6 & 2 & 18 & 1 & 8 & 6 & & 2 & 27 & 4 & 24 \\
\hline Tzyh-chyang br & idge & 2 & 4 & 18 & 6 & 4 & 6 & & 7 & 2 & 4 & 2 \\
\hline Huey-tong bridg & & 6 & 8 & 8 & 2 & 4 & 4 & & 0 & 32 & 0 & 48 \\
\hline
\end{tabular}


Table 4. Membership grade $A=\left[a_{1}, a_{2}\right]$ of assessment items decision making matrix

\begin{tabular}{|c|c|c|c|c|c|c|c|c|c|c|c|c|}
\hline \multicolumn{13}{|c|}{ General assessment items $\left[a_{1}\right]$} \\
\hline$\left[a_{1}\right]$ & $\begin{array}{c}\text { Guide } \\
\text { passage } \\
\text { road } \\
\text { embankment }\end{array}$ & $\begin{array}{c}\text { Guide } \\
\text { passage } \\
\text { protection } \\
\text { fence }\end{array}$ & $\begin{array}{l}\text { River } \\
\text { channel }\end{array}$ & $\begin{array}{c}\text { Guide } \\
\text { passage road } \\
\text { embankment } \\
\text { protection }\end{array}$ & $\begin{array}{l}\text { Abutment } \\
\text { foundation }\end{array}$ & Abutment & $\begin{array}{c}\text { Wing } \\
\text { masonry }\end{array}$ & $\begin{array}{c}\text { Friction } \\
\text { layer }\end{array}$ & $\begin{array}{l}\text { Drainage } \\
\text { appliance }\end{array}$ & $\begin{array}{c}\text { Stone curb } \\
\text { and } \\
\text { Pedestrian } \\
\text { way }\end{array}$ & $\begin{array}{c}\text { Balustrade } \\
\text { protection } \\
\text { fence }\end{array}$ & Other \\
\hline $\begin{array}{l}\text { Guang-hua } \\
\text { bridge }\end{array}$ & 0.8 & 0.8 & 0 & 0.4 & 0.7 & 1 & 0.6 & 0.6 & 0 & 0.6 & 0.4 & 0.4 \\
\hline $\begin{array}{l}\text { new Hwan-nan } \\
\text { bridge }\end{array}$ & 0 & 0 & 0.6 & 0 & 0 & 0.4 & 0.4 & 0 & 1 & 0.4 & 0 & 0 \\
\hline $\begin{array}{l}\text { old Hwan-nan } \\
\text { bridge }\end{array}$ & 1 & 1 & 0.7 & 0.4 & 1 & 1 & 0.4 & 1 & 0.6 & 0.4 & 1 & 1 \\
\hline Ay-gwo bridge & 0.8 & 0.8 & 0.6 & 1 & 1 & 0 & 1 & 1 & 0.4 & 1 & 1 & 0 \\
\hline $\begin{array}{l}\text { Tzyh-chyang } \\
\text { bridge }\end{array}$ & 0.8 & 0.8 & 1 & 1 & 0.6 & 1 & 1 & 0.4 & 1 & 0.4 & 0.2 & 1 \\
\hline $\begin{array}{l}\text { Huey-tong } \\
\text { bridge }\end{array}$ & 1 & 1 & 0.7 & 0.4 & 0.7 & 1 & 0 & 1 & 0.4 & 0 & 1 & 0.4 \\
\hline \multicolumn{13}{|c|}{ Detail assessment items $\left[a_{2}\right]$} \\
\hline$\left[a_{2}\right]$ & & $\begin{array}{l}\text { ubstructure } \\
\text { protection }\end{array}$ & $\begin{array}{c}\text { Pier } \\
\text { foundation }\end{array}$ & $\begin{array}{l}\text { Pier } \\
\text { shaft }\end{array}$ & $\begin{array}{c}\text { Supporting } \\
\text { mat }\end{array}$ & \multicolumn{2}{|c|}{$\begin{array}{c}\text { Prevention } \\
\text { earthquake } \\
\text { block }\end{array}$} & $\begin{array}{c}\text { Expansion } \\
\text { joint }\end{array}$ & \multicolumn{2}{|c|}{$\begin{array}{l}\text { Major } \\
\text { member }\end{array}$} & $\begin{array}{l}\text { Minor } \\
\text { nember }\end{array}$ & Deck \\
\hline \multicolumn{2}{|c|}{ Guang-hua bridge } & 1 & 0.167 & 0.383 & 0.375 & \multicolumn{2}{|r|}{1} & 0.333 & \multicolumn{2}{|c|}{0.161} & 0.094 & \\
\hline \multirow{2}{*}{\multicolumn{2}{|c|}{ new Hwan-nan bridge }} & 0 & 0.167 & 0 & 0 & \multicolumn{2}{|r|}{1} & 0.667 & \multicolumn{2}{|c|}{0.161} & 0.188 & 0.333 \\
\hline & & 0.667 & 0 & 1 & 0.75 & \multicolumn{2}{|r|}{0} & 1 & \multicolumn{2}{|c|}{1} & 1 & 0.75 \\
\hline \multicolumn{2}{|c|}{$\begin{array}{l}\text { old Hwan-nan bridge } \\
\text { Ay-owo bridge }\end{array}$} & 0.667 & 0 & 0.233 & 0.281 & \multirow{2}{*}{\multicolumn{2}{|c|}{0.5}} & 0.444 & \multicolumn{2}{|c|}{0.403} & 0.063 & 0.667 \\
\hline \multicolumn{2}{|c|}{ Tzyh-chyang bridge } & 0 & 0.333 & 0.233 & 1 & \multirow{2}{*}{\multicolumn{2}{|c|}{$\begin{array}{l}0.5 \\
0\end{array}$}} & 1 & 0 & & 0.063 & 0.056 \\
\hline \multicolumn{2}{|c|}{ Huey-tong bridge } & 0.667 & 1 & 0.067 & 0.375 & & & 0 & & & 0 & 1 \\
\hline
\end{tabular}

Table 5. Interval number complementary judgment matrix $A^{*}$ of assessment items

\begin{tabular}{|c|c|c|c|c|c|c|c|c|c|c|c|c|}
\hline \multicolumn{13}{|c|}{ General assessment items } \\
\hline & $\begin{array}{c}\text { Guide } \\
\text { passage } \\
\text { road } \\
\text { embankment }\end{array}$ & $\begin{array}{c}\text { Guide } \\
\text { passage } \\
\text { protection } \\
\text { fence }\end{array}$ & $\begin{array}{l}\text { River } \\
\text { channel }\end{array}$ & $\begin{array}{c}\text { Guide } \\
\text { passage road } \\
\text { embankment } \\
\text { protection }\end{array}$ & $\begin{array}{l}\text { Abutment } \\
\text { foundation }\end{array}$ & Abutment & $\begin{array}{l}\text { Wing } \\
\text { masonry }\end{array}$ & $\begin{array}{c}\text { Friction } \\
\text { layer }\end{array}$ & $\begin{array}{l}\text { Drainage } \\
\text { appliance }\end{array}$ & $\begin{array}{l}\text { Stone curb } \\
\text { and } \\
\text { Pedestrian } \\
\text { way }\end{array}$ & $\begin{array}{c}\text { Balustrade } \\
\text { protection } \\
\text { fence }\end{array}$ & Other \\
\hline \multirow{2}{*}{$\begin{array}{l}\text { Guide } \\
\text { passage } \\
\text { road } \\
\text { embankment }\end{array}$} & \multirow[b]{2}{*}{0.5} & 0.561 & 0.439 & 0.439 & 0.138 & 0.138 & 0.138 & 0.439 & 0.439 & 0.561 & 0.439 & 0.5 \\
\hline & & 0.5 & 0.5 & 0.561 & 0.439 & 0.429 & 0.439 & 0.561 & 0.5 & 0.5 & 0.561 & 0.675 \\
\hline \multirow{2}{*}{$\begin{array}{l}\text { Guide } \\
\text { passage } \\
\text { protection } \\
\text { fence }\end{array}$} & 0.439 & \multirow{2}{*}{0.5} & 0.325 & 0.439 & 0.138 & 0.138 & 0.138 & 0.439 & 0.325 & 0.439 & 0.439 & 0.5 \\
\hline & 0.5 & & 0.5 & 0.5 & 0.225 & 0.325 & 0.325 & 0.5 & 0.5 & 0.561 & 0.5 & 0.561 \\
\hline \multirow{2}{*}{$\begin{array}{l}\text { River } \\
\text { channel }\end{array}$} & 0.500 & 0.561 & \multirow{2}{*}{0.5} & 0.5 & 0.138 & 0.325 & 0.325 & 0.5 & 0.5 & 0.561 & 0.5 & 0.561 \\
\hline & 0.561 & 0.675 & & 0.561 & 0.1439 & 0.439 & 0.439 & 0.561 & 0.561 & 0.673 & 0.561 & 0.675 \\
\hline \multirow{2}{*}{$\begin{array}{l}\text { Guide } \\
\text { passage road } \\
\text { embankment } \\
\text { protection }\end{array}$} & 0.439 & 0.439 & 0.439 & \multirow{2}{*}{0.5} & 0.138 & 0.138 & 0.138 & 0.439 & 0.429 & 0.439 & 0.439 & 0.5 \\
\hline & 0.561 & 0.561 & 0.5 & & 0.439 & 0.439 & 0.439 & 0.561 & 0.5 & 0.561 & 0.561 & 0.675 \\
\hline Abutment & 0.675 & 0.862 & 0.675 & 0.862 & & 0.439 & 0.561 & 0.675 & 0.675 & 0.862 & 0.675 & 0.862 \\
\hline foundation & 0.9 & 0.9 & 0.862 & 0.675 & 0.5 & 0.5 & 0.675 & 0.9 & 0.862 & 0.9 & 0.9 & 0.9 \\
\hline \multirow{2}{*}{ Abutment } & 0.675 & 0.675 & 0.561 & 0.675 & 0.439 & \multirow[b]{2}{*}{0.5} & 0.5 & 0.675 & 0.561 & 0.675 & 0.675 & 0.675 \\
\hline & 0.862 & 0.862 & 0.675 & 0.561 & 0.5 & & 0.561 & 0.862 & 0.675 & 0.862 & 0.862 & 0.9 \\
\hline
\end{tabular}


Table 5. (Contiuned)

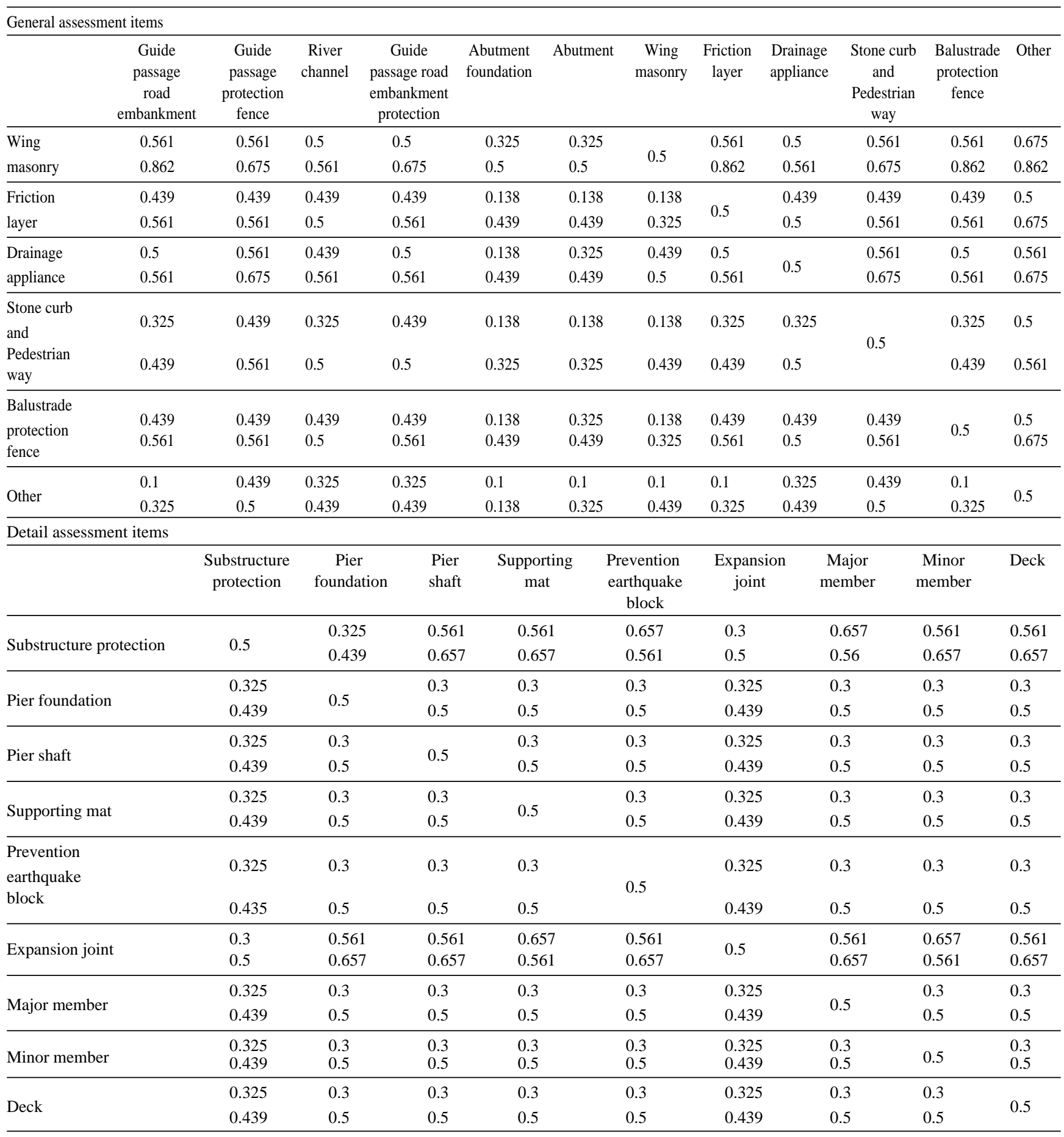

\section{(2) Objective weight method}

Based on the composite member DER values of six existing RC bridges in Taiwan, one may perform the calculation of membership function for establishing decision-making matrix. After normalizing to deci- sion-making matrix, one has the normalization decision-making matrix, A, as shown in Table 4. Using Eq. (35) and Table 4, one establishes the objective calculation matrix, $\mathrm{P}$, as denoted in Table 8. Using Table 8 and Eq. (36), one can calculate E value as follows: 
Table 6. Weight interval $W_{i}^{*}$ obtained from interval number complementary judgment matrix

\begin{tabular}{lr}
\hline \multicolumn{2}{c}{ General assessment items } \\
\hline Assessment items & Weight interval \\
Guide passage road embankment & {$[0.0589,0.0992]$} \\
Guide passage protection fence & {$[0.0530,0.0899]$} \\
River channel & {$[0.0681,0.1068]$} \\
Guide passage road embankment & {$[0.0558,0.1012]$} \\
protection & {$[0.1035,0.1522]$} \\
Abutment foundation & {$[0.0906,0.1395]$} \\
Abutment & {$[0.0763,0.1395]$} \\
Wing masonry & {$[0.0558,0.1012]$} \\
Friction layer & {$[0.0687,0.1078]$} \\
Drainage appliance & {$[0.0487,0.0888]$} \\
Stone curb and Pedestrian way & {$[0.0582,0.0993]$} \\
Balustrade protection fence & {$[0.0367,0.0754]$} \\
Other & \\
\hline & Wetail assessment items \\
\hline Assessment items & {$[0.0849,0.1253]$} \\
Substructure protection & {$[0.1043,0.1625]$} \\
Pier foundation & {$[0.1007,0.1625]$} \\
Pier shaft & {$[0.0693,0.1108]$} \\
Supporting mat & {$[0.0693,0.1108]$} \\
Prevention earthquake block & {$[0.0851,0.1253]$} \\
Expansion joint & {$[0.1043,0.1608]$} \\
Major member & {$[0.0851,0.1253]$} \\
Minor member & {$[0.1007,0.1625]$} \\
Deck & \\
\hline
\end{tabular}

general assessment items

$$
\begin{aligned}
& E_{1}= {\left[\begin{array}{lllll}
0.8948 & 0.8948 & 0.8875 & 0.8409 & 0.8891 \\
0.8734 & 0.8616 & 0.8745 & 0.8816 & 0.8548 \\
& 0.8253 & 0.7208
\end{array}\right]^{\mathrm{T}} } \\
&
\end{aligned}
$$

detail assessment items

$$
\begin{aligned}
E_{2}= & {\left[\begin{array}{lllll}
0.7640 & 0.6079 & 0.7205 & 0.8334 & 0.7421 \\
0.8517 & 0.7722 & 0.5417 & 0.7774
\end{array}\right]^{\mathrm{T}} }
\end{aligned}
$$

The larger value of $\mathrm{E}$ is responded that the damage state of bridge member is more severe.

Using Eq. (37), one calculates the objective weight of assessment item $C_{j}$ as shown in the following:

general assessment items

$$
\begin{aligned}
& v_{1}= {\left[\begin{array}{lllll}
0.0611 & 0.0611 & 0.0654 & 0.0924 & 0.0644 \\
0.0736 & 0.0804 & 0.0729 & 0.0804 & 0.0843 \\
0.1015 & 0.1623
\end{array}\right]^{\mathrm{T}} } \\
&
\end{aligned}
$$

detail assessment items

$$
v_{2}=\left[\begin{array}{llllll}
0.0988 & 0.1641 & 0.1170 & 0.0698 & 0.1079
\end{array}\right.
$$$$
\left.\begin{array}{llll}
0.0621 & 0.0954 & 0.1918 & 0.0932
\end{array}\right]^{\mathrm{T}}
$$

Taking $\alpha=0.6, \beta=0.4$ and using Eq. (19), one obtains the weights of assessment items as follows:

$$
\begin{aligned}
& \text { general assessment items } \\
& w_{1}=\left[\begin{array}{lllll}
0.0673 & 0.0586 & 0.0788 & 0.0795 & 0.1157 \\
0.1102 & 0.1005 & 0.0716 & 0.0858 & 0.0654 \\
0.0832 & 0.0833
\end{array}\right]^{\mathrm{T}} \\
& \\
& \text { detail assessment items } \\
& w_{2}=\left[\begin{array}{lllll}
0.0955 & 0.1580 & 0.1367 & 0.0616 & 0.0769 \\
0.0809 & 0.1305 & 0.1328 & 0.1271
\end{array}\right]^{\mathrm{T}}
\end{aligned}
$$

The value of weight implies the importance of bridge member. Thus, one has the importance ranking of bridge member:

general assessment items: Abutment foundation $\rightarrow$ Abutment $\rightarrow$ Wing masonry $\rightarrow$ Drainage appliance $\rightarrow$ Other $\rightarrow$ Balustrade protection fence $\rightarrow$ Guide passage road embankment protection $\rightarrow$ River channel $\rightarrow$ Friction layer $\rightarrow$ Guide passage road embankment $\rightarrow$ Guide passage protection fence

detail assessment items: Pier foundation $\rightarrow$ Pier shaft $\rightarrow$ Minor member $\rightarrow$ Major member $\rightarrow$ Deck $\rightarrow$ Substructure protection $\rightarrow$ Expansion joint $\rightarrow$ Prevention earthquake block $\rightarrow$ Supporting mat

Now, one introduces two formulas of comparison matrix method [13] as follows:

$$
\overline{D_{n}}=\overline{w_{n}} R_{n, m}
$$

where $\overline{D_{n}}$ is the fuzzy synthesis evaluation matrix, $\overline{w_{n}}$ $(\mathrm{n}=1,2)$ is the weight, and $R_{n, m}(\mathrm{n}=1,2, \mathrm{~m}=1,2, \ldots$, $21)$ is the relationship between the membership grades.

$$
\bar{B}=\overline{A_{n}} \overline{D_{n}}
$$

where $\bar{B}$ is the fuzzy synthesis evaluation result and $\overline{A_{n}}$ is the weight vector evaluated by expert. The optimal repair ranking can be determined by using Eq. (39). The more the value of $\bar{B}$ has, the better the priority selection to decision-making objective is.

Substituting the values of weight into Eq. (39) and using the DER evaluation method [13], one has the repair ranking of six existing RC bridges in Taiwan as follows:

Proposed method: old Hwan-nan bridge $\rightarrow$

$$
\bar{B}=\quad 0.7117
$$

Huey-tong bridge $\rightarrow$ Ay-gwo bridge $\rightarrow$

$$
0.4911 \quad 0.4201
$$

Tzyh-chyang bridge $\rightarrow$ Guang-hua bridge $\rightarrow$

$$
0.4006 \quad 0.3871
$$


Table 7. Possibility matrix $\boldsymbol{P}^{*}$

\begin{tabular}{|c|c|c|c|c|c|c|c|c|c|c|c|c|c|}
\hline \multicolumn{14}{|c|}{ General assessment items } \\
\hline & $\begin{array}{c}\text { Guide } \\
\text { passage } \\
\text { road } \\
\text { embankment }\end{array}$ & $\begin{array}{l}\text { Guide } \\
\text { passage } \\
\text { protection } \\
\text { fence }\end{array}$ & $\begin{array}{c}\text { River } \\
\text { channel }\end{array}$ & $\begin{array}{c}\text { Guide } \\
\text { passage road } \\
\text { embankment } \\
\text { protection }\end{array}$ & $\begin{array}{l}\text { Abutment } \\
\text { foundation }\end{array}$ & Abutment & $\begin{array}{l}\text { Wing } \\
\text { masonry }\end{array}$ & $\begin{array}{c}\text { Friction } \\
\text { layer }\end{array}$ & $\begin{array}{l}\text { Drainage } \\
\text { appliance }\end{array}$ & $\begin{array}{l}\text { Stone curb } \\
\text { and } \\
\text { pedestrian } \\
\text { way }\end{array}$ & $\begin{array}{l}\text { Balustrade } \\
\text { protection } \\
\text { fence }\end{array}$ & Other & $\begin{array}{l}\text { Raw } \\
\text { sum }\end{array}$ \\
\hline $\begin{array}{l}\text { Guide passage } \\
\text { road embankment }\end{array}$ & 0.5000 & 0.5981 & 0.3938 & 0.5063 & 0.0000 & 0.0960 & 0.2437 & 0.5063 & 0.3839 & 0.6276 & 0.5036 & 0.7905 & 5.1498 \\
\hline $\begin{array}{l}\text { Guide passage } \\
\text { protection fence }\end{array}$ & 0.4019 & 0.5000 & 0.2889 & 0.4144 & 0.0000 & 0.0000 & 0.1505 & 0.4144 & 0.2790 & 0.5348 & 0.4067 & 0.7034 & 4.0941 \\
\hline River channel & 0.6062 & 0.7111 & 0.5000 & 0.6063 & 0.0371 & 0.1844 & 0.3300 & 0.6063 & 0.4895 & 0.7376 & 0.6087 & 0.9051 & 6.3212 \\
\hline $\begin{array}{l}\text { Guide passage } \\
\text { road embankment } \\
\text { protection }\end{array}$ & 0.4937 & 0.5856 & 0.3937 & 0.5000 & 0.0000 & 0.1117 & 0.2512 & 0.5000 & 0.3844 & 0.6138 & 0.4971 & 0.7608 & 5.0982 \\
\hline $\begin{array}{l}\text { Abutment } \\
\text { foundation }\end{array}$ & 1.0000 & 1.0000 & 0.9629 & 1.0000 & 0.5000 & 0.6314 & 0.7413 & 1.0000 & 0.9518 & 1.0000 & 1.0000 & 1.0000 & 10.7874 \\
\hline Abutment & 0.9040 & 1.0000 & 0.8156 & 0.8883 & 0.3686 & 0.5000 & 0.6160 & 0.8883 & 0.8051 & 1.0000 & 0.9035 & 1.0000 & 9.6894 \\
\hline Wing masonry & 0.7563 & 0.8495 & 0.6700 & 0.7488 & 0.2587 & 0.3840 & 0.5000 & 0.7488 & 0.6606 & 0.8663 & 0.7571 & 1.0000 & 8.2001 \\
\hline Friction layer & 0.4937 & 0.5856 & 0.3937 & 0.5000 & 0.0000 & 0.1117 & 0.2512 & 0.5000 & 0.3844 & 0.6138 & 0.4971 & 0.7668 & 5.0982 \\
\hline $\begin{array}{l}\text { Drainage } \\
\text { appliance }\end{array}$ & 0.6161 & 0.7210 & 0.5105 & 0.6156 & 0.0482 & 0.1949 & 0.3394 & 0.6156 & 0.5000 & 0.7461 & 0.6185 & 0.9139 & 6.4397 \\
\hline $\begin{array}{l}\text { Stone curb and } \\
\text { Pedestrian way }\end{array}$ & 0.3724 & 0.4652 & 0.2633 & 0.3862 & 0.0000 & 0.0000 & 0.1337 & 0.3862 & 0.2539 & 0.5000 & 0.3773 & 0.6612 & 3.7993 \\
\hline $\begin{array}{l}\text { Balustrade } \\
\text { protection fence }\end{array}$ & 0.4964 & 0.5933 & 0.3913 & 0.5029 & 0.0000 & 0.0965 & 0.2429 & 0.5029 & 0.3815 & 0.6227 & 0.5000 & 0.7838 & 5.1143 \\
\hline Other & 0.2095 & 0.2966 & 0.0949 & 0.2332 & 0.0000 & 0.0000 & 0.0000 & 0.2332 & 0.0861 & 0.3388 & 0.2162 & 0.5000 & 2.2084 \\
\hline \multicolumn{14}{|c|}{ Detail assessment items } \\
\hline & $\begin{array}{r}\text { Substructur } \\
\text { protection }\end{array}$ & $\begin{array}{r}\mathrm{P} \\
\text { founc }\end{array}$ & ation & $\begin{array}{l}\text { Pier } \\
\text { shaft }\end{array}$ & $\begin{array}{l}\text { Supporting } \\
\text { mat }\end{array}$ & $\begin{array}{c}\text { Prevention } \\
\text { earthquake } \\
\text { block }\end{array}$ & \multicolumn{2}{|c|}{$\begin{array}{l}\text { Expansion } \\
\text { joint }\end{array}$} & $\begin{array}{c}\text { Major } \\
\text { member }\end{array}$ & $\begin{array}{l}\text { Minor } \\
\text { member }\end{array}$ & \multicolumn{2}{|l|}{ Deck } & $\begin{array}{l}\text { Raw } \\
\text { sum }\end{array}$ \\
\hline $\begin{array}{l}\text { Substructure } \\
\text { protection }\end{array}$ & 0.5000 & 0.2 & & 0.2405 & 0.6835 & 0.6835 & \multicolumn{2}{|c|}{0.4989} & 0.2163 & 0.4989 & \multicolumn{2}{|l|}{0.2405} & 3.7785 \\
\hline Pier foundation & 0.7837 & 0.5 & & 0.5079 & 0.9337 & 0.9337 & \multicolumn{2}{|c|}{0.7833} & 0.5000 & 0.7833 & \multicolumn{2}{|l|}{0.5079} & 6.2335 \\
\hline pier shaft & 0.7595 & 0.4 & & 0.5000 & 0.9020 & 0.9020 & \multicolumn{2}{|c|}{0.7591} & 0.4921 & 0.7591 & \multicolumn{2}{|l|}{0.5000} & 6.0657 \\
\hline Supporting mat & 0.3165 & 0.0 & & 0.0980 & 0.5000 & 0.5000 & \multicolumn{2}{|c|}{0.3150} & 0.0663 & 0.3150 & \multicolumn{2}{|l|}{0.0980} & 2.2752 \\
\hline $\begin{array}{l}\text { Prevention } \\
\text { earthquake block }\end{array}$ & 0.3165 & 0.0 & & 0.0980 & 0.5000 & 0.5000 & \multicolumn{2}{|c|}{0.3150} & 0.0663 & 0.3150 & \multicolumn{2}{|l|}{0.0980} & 2.2752 \\
\hline Expansion joint & 0.5011 & 0.2 & & 0.2409 & 0.6850 & 0.6850 & \multicolumn{2}{|c|}{0.5000} & 0.2167 & 0.5000 & \multicolumn{2}{|l|}{0.2409} & 3.7863 \\
\hline Major member & 0.7837 & 0.5 & & 0.5079 & 0.9337 & 0.9337 & \multicolumn{2}{|c|}{0.7833} & 0.5000 & 0.7833 & \multicolumn{2}{|l|}{0.5079} & 6.2335 \\
\hline Minor member & 0.5011 & 0.2 & & 0.2409 & 0.6850 & 0.6850 & \multicolumn{2}{|c|}{0.5000} & 0.2167 & 0.5000 & \multicolumn{2}{|l|}{0.2409} & 3.7863 \\
\hline Deck & 0.7595 & 0.4 & & 0.5000 & 0.9020 & 0.9020 & \multicolumn{2}{|c|}{0.7591} & 0.4921 & 0.7591 & \multicolumn{2}{|l|}{0.5000} & 6.0657 \\
\hline
\end{tabular}

new Hwan-nan bridge 0.2407

DER evaluation method: old Hwan-nan bridge $\rightarrow$

$$
\mathrm{PI}=\quad 45.932
$$

Huey-tong bridge $\rightarrow$ Ay-gwo bridge $\rightarrow$

$$
69.837 \quad 79.041
$$

Tzyh-chyang bridge $\rightarrow$ Guang-hua bridge $\rightarrow$

$$
80.172 \quad 84.618
$$

new Hwan-nan bridge

$$
87.382
$$

where PI is the priority index.
The result indicates that the predicted repair ranking obtained from the proposed method is the same as that of the DER evaluation method. This means that the weight distribution of assessment items gained from the proposed method is coincident with that of the DER evaluation method. This implies that the weight for each items of bridge with bestridden river in the DER evaluation method as shown in Table 9 is reasonable.

\section{Bridge with non-bestridden river}

Let the river channel, guide passage road embanknent protection, abutment and wing masonry of general assessment items take out from Table 9. Now, one 
Table 8. Objective calculation matrix $P=\left[\begin{array}{ll}P_{1} & P_{2}\end{array}\right]$

\begin{tabular}{|c|c|c|c|c|c|c|c|c|c|c|c|c|}
\hline \multicolumn{13}{|c|}{ General assessment items } \\
\hline & $\begin{array}{c}\text { Guide } \\
\text { passage } \\
\text { protection } \\
\text { embankment }\end{array}$ & $\begin{array}{c}\text { Guide } \\
\text { passage } \\
\text { fence }\end{array}$ & $\begin{array}{c}\text { River } \\
\text { channel } \\
\text { protection }\end{array}$ & $\begin{array}{c}\text { Guide } \\
\text { passage road } \\
\text { embankment } \\
\text { protection }\end{array}$ & $\begin{array}{l}\text { Abutment } \\
\text { foundation }\end{array}$ & Abutment & $\begin{array}{l}\text { Wing } \\
\text { masonry }\end{array}$ & $\begin{array}{cc}\text { Friction } & \text { I } \\
\text { layer } & \text { a }\end{array}$ & $\begin{array}{l}\text { Drainage } \\
\text { appliance }\end{array}$ & $\begin{array}{l}\text { Stone curb } \\
\text { and } \\
\text { Pedestrian } \\
\text { way }\end{array}$ & $\begin{array}{l}\text { Balustrade } \\
\text { protection } \\
\text { fence }\end{array}$ & Other \\
\hline $\begin{array}{l}\text { Guang-hua } \\
\text { bridge }\end{array}$ & 0.1818 & 0.1818 & 0 & 0.125 & 0.175 & 0.2273 & 0.1765 & 0.15 & 0 & 0.2143 & 0.1111 & 0.1429 \\
\hline $\begin{array}{l}\text { New Hwan-nan } \\
\text { bridge }\end{array}$ & 0 & 0 & 0.1667 & 0 & 0 & 0.0909 & 0.1176 & 00 & 0.2941 & 0.1429 & 0 & 0 \\
\hline $\begin{array}{l}\text { old Hwan-nan } \\
\text { bridge }\end{array}$ & 0.2273 & 0.2273 & 0.1944 & 0.125 & 0.25 & 0.2273 & 0.1176 & 0.25 & 0.1765 & 0.1429 & 0.2778 & 0.3571 \\
\hline Ay-gwo bridge & 0.1818 & 0.1818 & 0.1667 & 0.3125 & 0.25 & 0 & 0.2941 & 0.25 & 0.1176 & 0.3571 & 0.2778 & 0 \\
\hline $\begin{array}{l}\text { Tzyh-chyang } \\
\text { bridge }\end{array}$ & 0.1818 & 0.1818 & 0.2778 & 0.3125 & 0.15 & 0.2273 & 0.2941 & 0.1 & 0.2941 & 0.1429 & 0.0556 & 0.3571 \\
\hline $\begin{array}{l}\text { Huey-tong } \\
\text { bridge }\end{array}$ & 0.2273 & 0.2273 & 0.1944 & 0.125 & 0.175 & 0.2273 & 0 & 0.25 & 0.1176 & 0 & 0.2778 & 0.1429 \\
\hline & \multicolumn{2}{|c|}{$\begin{array}{l}\text { Substructure } \\
\text { protection }\end{array}$} & $\begin{array}{c}\text { Pier } \\
\text { foundation }\end{array}$ & $\begin{array}{l}\text { Pier } \\
\text { shaft }\end{array}$ & \multicolumn{2}{|c|}{$\begin{array}{l}\text { Supporting } \\
\text { mat }\end{array}$} & $\begin{array}{l}\text { Prevention } \\
\text { earthquake } \\
\text { block }\end{array}$ & $\begin{array}{c}\text { Expansion } \\
\text { joint }\end{array}$ & \multicolumn{2}{|c|}{$\begin{array}{l}\text { Major } \\
\text { member }\end{array}$} & $\begin{array}{l}\text { Minor } \\
\text { member }\end{array}$ & Deck \\
\hline Guang-hua bridge & \multicolumn{2}{|c|}{0.3332} & 0.1002 & 0.1999 & \multicolumn{2}{|c|}{0.1348} & 0.3333 & 0.0967 & \multicolumn{2}{|c|}{0.0729} & 0.0668 & 0 \\
\hline new Hwan-nan bri & \multicolumn{2}{|c|}{0} & 0.1002 & 0 & \multicolumn{2}{|l|}{0} & 0.3333 & 0.1937 & \multicolumn{2}{|c|}{0.0729} & 0.1335 & 0.1187 \\
\hline old Hwan-nan bric & dge & 2223 & 0 & 0.5219 & \multicolumn{2}{|c|}{0.2697} & 0 & 0.2904 & \multicolumn{2}{|c|}{0.4527} & 0.7102 & 0.2673 \\
\hline Ay-gwo bridge & & 2223 & 0 & 0.1216 & \multicolumn{2}{|c|}{0.101} & 0.1667 & 0.1289 & \multicolumn{2}{|c|}{0.1824} & 0.0447 & 0.2377 \\
\hline \multicolumn{2}{|c|}{ Tzyh-chyang bridge } & & 0.1998 & 0.1216 & \multicolumn{2}{|c|}{0.3596} & 0.1667 & 0.2904 & \multicolumn{2}{|c|}{0} & 0.0447 & 0.02 \\
\hline \multicolumn{2}{|l|}{ Huey-tong bridge } & 2223 & 0.5999 & 0.035 & 0.134 & & 0 & 0 & & 91 & 0 & 0.3564 \\
\hline
\end{tabular}

Table 9. Weight for each item of bridge with bestridden river in DER evaluation method

\begin{tabular}{|c|c|c|c|c|c|}
\hline Item & Weight & Item & Weight & Item & Weight \\
\hline Substructure protection & 6 & Minor element(diaphragm) & 6 & Abutment & 6 \\
\hline Pier foundation & 8 & Deck or hinged plate & 7 & Wing masonry/retaining wall & 5 \\
\hline Pier shaft & 7 & Guide passage Road embankment & 3 & Friction layer & 3 \\
\hline Supporting mat & 5 & Guide passage protection fence & 2 & Drainage appliance & 4 \\
\hline Shear key/Restrained cable & 5 & River channel & 3 & Stone curb and pedestrian way & 2 \\
\hline Expansion joint & 6 & Guide passage, road embankment & 2 & Balustrade/ Protection fence & 3 \\
\hline \multirow[t]{2}{*}{ Major element (girder) } & 8 & protection & 5 & Other & 1 \\
\hline & & Abutment foundation & 6 & & \\
\hline
\end{tabular}

carries out the weight distribution. The weights of general assessment items and the importance ranking of bridge member obtained from the proposed method are respectively described as follows:

$w=\left[\begin{array}{ccc}\text { Guide passage } & \text { Guide passage } & \text { Abutment } \\ \text { road embankment } & \text { protection fence } & \text { foundation } \\ 0.1038 & 0.0922 & 0.1685\end{array}\right.$

Friction Drainage Stone curb and layer appliance pedestrian way
0.1123
0.1068

$\left.\begin{array}{cc}\text { Balustrade } & \text { other } \\ \text { protection fence } & \\ 0.1345 & 0.1492\end{array}\right]$

and

Abutment foundation $\rightarrow$ Other $\rightarrow$ Balustrade protection fence $\rightarrow$ Drainage appliance $\rightarrow$ Friction layer $\rightarrow$ Stone curb and pedestrian way $\rightarrow$ Guide passage road embamkment $\rightarrow$ Guide passage protection fence.

The weights of assessment items are listed in Table 10. In a similar manner, one obtains the repair ranking as 
Table 10. Weight for each item of bridge without bestridden river in DER evaluation method

\begin{tabular}{|c|c|c|c|c|c|}
\hline Item & Weight & Item & Weight & Item & Weight \\
\hline Substructure protection & 7 & Minor element(diaphragm) & 10 & Abutment & -- \\
\hline Pier foundation & 11 & Deck or hinged plate & 10 & Wing masonry/retaining wall & -- \\
\hline Pier shaft & 11 & Guide passage road embankment & 3 & Friction layer & 3 \\
\hline Supporting mat & 5 & Guide passage protection fence & 2 & Drainage appliance & 4 \\
\hline Shear key/Restrained cable & 5 & River channel & -- & Stone curb and pedestrian way & 2 \\
\hline Expansion joint & 7 & Guide passage, road embankment & & Balustrade/Protection fence & 3 \\
\hline \multirow[t]{2}{*}{ Major element (girder) } & 10 & protection & & Other & 1 \\
\hline & & Abutment foundation & 7 & & \\
\hline
\end{tabular}

shown in the following:

Proposed method: old Hwan-nan bridge $\rightarrow$

$$
\bar{B}=\quad 0.7297
$$

Huey-tong bridge $\rightarrow$ Ay-gwo bridge $\rightarrow$

$$
0.5 \quad 0.4259
$$

Guang-hua bridge $\rightarrow$ Tzyh-chyang bridge $\rightarrow$

$$
0.3852 \quad 0.3743
$$

new Hwan-nan bridge

$$
0.2214
$$

DER evaluation method: old Hwan-nan bridge $\rightarrow$

$$
\mathrm{PI}=\quad 43.1127
$$

Huey-tong bridge $\rightarrow$ Ay-gwo bridg $\rightarrow$

$$
69.3326 \quad 79.1118
$$

Guang-hua bridge $\rightarrow$ Tzyh-chyang bridge $\rightarrow$

$$
81.7708 \quad 82.0107
$$

new Hwan-nan bridge

84.346

The result displays that the predicted repair ranking obtained from the proposed method is agreement with that of the DER evaluation method. This means that Table 10 is very suitable for evaluating the existing $\mathrm{RC}$ bridges with non-bestridden river.

\section{CONCLUSIONS}

In this present study, the least squares technique in conjunction with comparison matrix method has been described. The proposed and DER evaluation methods were adopted to evaluate the repair ranking of the six existing RC bridges in Taiwan. The evaluation repair ranking results obtained from both the proposed and DER evaluation methods for the existing six RC bridges in Taiwan with and without bestridden rivers were respectively the same as follows: 1. old Hwan-nan, 2. Hueytong, 3. Ay-gwo, 4. Tzyh-chyang, 5. Guang-hua, 6. new Hwan-nan, and 1. old Hwan- nan, 2. Huey- tong, 3. Aygwo, 4. Guang-hua, 5. Tzyh-chyang, 6. new Hwan-nan.
The proposed method considered both the subjective and objective weights is good in assessment with the DER evaluation method. The predicted results of illustrative example denote that the proposed method is full of serviceability, efficiency and reliability. This proposed method is in addition simple and practical. The proposed method appears to be a useful and powerful method in determining the repair ranking for existing RC bridges. Furthermore, Table 10 is very fitting for assessing the existing RC bridges without bestridden river. The present work to Table 10 is acted as a substitute for the defect of DER evaluation method without the weight for each item of bridge without bestridden river.

\section{ACKNOWLEDGMENTS}

The authors would like to thank the Join Engineering Consultant for financial support for this study.

\section{NOMENCLATURE}

A normalization decision making matrix

$\mathrm{A}^{*} \quad$ interval number complementary judgment matrix

$\overline{A_{n}} \quad$ weight vector evaluated by expert

$\mathrm{a}_{\mathrm{ij}} \quad$ membership grade of decision marking

B assessment items set

D decision making set

$\mathrm{D}_{\mathrm{n}} \quad$ fuzzy synthesis evaluation matrix

$E_{j} \quad$ output information entropy of assessment item

f function

$\mathrm{H}(\mathrm{w})$ decision making value

$\mathrm{L}(\mathrm{x}, \lambda)$ Lagrange's function

$\mathrm{P}^{*} \quad$ possible matrix

$\mathrm{P}^{*}(\mathrm{a} \geq \mathrm{b})$ reliability when $\mathrm{a} \geq \mathrm{b}$

PI priority index

$\mathrm{R} \quad$ relative membership grade matrix

$R_{n, m} \quad$ relative between the membership grades

$\mathrm{r}_{\mathrm{ij}} \quad$ relative membership grade 
$\mathrm{u} \quad$ subjective weight

$\mathrm{v} \quad$ objective weight

w weight

$\mathrm{w}^{*} \quad$ interval number weight vector

$\mathrm{X}$ decision making matrix

$\mathrm{x} \quad$ variable

$\alpha \quad$ the importance of subjective weight

$\beta \quad$ the importance of objective weight

$\lambda \quad$ Lagrange's multiplier

\section{REFERENCES}

1. Brown, C.B. and Yao, J.T.P., "Fuzzy Sets and Structural Engineering," Journal of Structural Engineering ASCE, Vol. 109, No. 5, pp. 1211-1225 (1983).

2. Chen, T., Decision-Making Analysis, Science Publisher, Beijing, China, pp. 192-186 (1987). (in Chinese)

3. Chen, S., Engineering Fuzzy Set Theory and Application, National Defense Industry Publisher, Beijing, China, (1998). (in Chinese)

4. Cheng, M.X., "Weighting Sum Method of Binomial Coefficient for Treating Multiple Objective Decision Making Problem," System Engineering Theory and Practice, No. 4, pp. 23-26 (1983). (in Chinese)

5. Chou, K.C. and Yuan, J., "Fuzzy-Bayesian Approach to Reliability of Existing Structures," Journal of Structural Engineering ASCE, Vol. 119, No. 11, pp. 3276-3290 (1993).

6. Chu, A.T.W., Kaleba, R.E., Spingarn, K., “A Comparison of Two Methods for Determining the Weights of Beinging to Fuzzy Set," Journal of Optimization Theory and Application, Vol. 27, pp. 531-538 (1979).

7. CSIR, Taiwan Area National Freeway Bureau Bridge Management System: Description of Modulus and Computer Options, Pretoria, South Africa (1994).

8. Hwang, C.L. and Lin, M.J., Group Decision Making under Multiple Criteria: Method and Applications, Springer Verlag, New York, USA, (1987).

9. Jenn, C.C., "Determination Method of Weight Survey in Multiple Objective Decision Making," System Engineering Theory and Practice, No. 2 , pp. 16-27 (1987). (in Chinese)

10. Join Engineering Consultants, General Inspection Guideline of Public Road Bridge, Taiwan Area National Freeway Bureau Ministry of Communications, Taipei, R.O.C. (1996). (in Chinese)

11. Join Engineering Consultants, Report on the Detection Engineering of Bridges in Taipei, Department of Curing Engineering, Taipei Municipal Government, R.O.C. (1999). (in Chinese)

12. Li, D.F., "Complicated Fuzzy System Multiple Layer, Multiple Objective, Multiple Persons Decision-Making Theoretical Model and Applications," Ph.D Dissertaion,
Dalien University of Technology, Dalien, China (1995). (in Chinese)

13. Liang, M.T., Lin, C.M., and Yeh, C.J., "Comparison Matrix Method and Its Applications to Damage Evaluation for Existing Reinforced Concrete Bridges," Journal of Marine Science and Technology, Vol. 11, No. 2, pp 113 (2003).

14. Liu, J.X., "A Decision Making Method of Leaning on Good Information with Respect to Index Attribute," System Engineering Theory and Practice, No. 2, pp. 5457 (1998). (in Chinese)

15. Luh, M.S., "Weight Coefficient in Multiple Objective Decision Making," System Engineering Theory and Practice, No. 4, pp. 77-78 (1986). (in Chinese)

16. Ren, P., Mathematical Foundation of Fuzzy Information Treatment, Kweichow Technology Publisher, China, (1995). (in Chinese)

17. Satty. T.L., "A Scaling Method for Priorities in Hierarchical Structures," Journal of Mathematical Psychology, Vol. 15, pp. 234-281 (1977). .

18. Saaty, T.L., "Modeling Unstructured Decision Problems-The Theory of Analytical Hierarchies," Mathematics and Computers in Simulation, Vol. 20, pp. 147-158 (1978).

19. Saaty, T.L., The Analytic Hierarchy Process: Planning, Priority Setting, Resource Allocation, McGraw-Hill, New York (1980).

20. Sinotech Engineering Consultants, Report on the Detection Engineering of Bridges in Taipei, Department of Curing Engineering, Taipei Municipal Government, R.O.C. (1998). (in Chinese)

21. Wang, Y.M., "Application of Infinite Alternative Multiple Objective Decision- Making Method to Performing Finite Alternative Multiple Objective Decision-Making," Control and Decision Making, Vol. 8, No. 1, pp. 25-29 (1993). (in Chinese)

22. Wang, H.Z., Zhou, L., and He, B.F., "Study on Models for Sorting and Selecting Hydraulic and Hydroelectric Engineering Investment Project," Journal of Zhengzhon University of Technology, Vol. 22, No. 1, pp. 56-60 (2001). (in Chinese)

23. Wei, W. and Feny, J., "Study on Multiobjective Weights Combination Assigning Method," System Engineering and Electronics, No. 2, pp. 14-16 (1998). (in Chinese)

24. Xu, Z.S. and Sun, Z.D., "A Method Based on Satisfactory Degree of Alternative for Uncertainly Multi Attribution Decision-Making," System Engineering, Vol. 19, No. 3, pp. 76-79 (2001).

25. Zhao, Z. and Chen, C., "Concrete Bridge Deterioration Diagnosis Using Fuzzy Inference System," Advanced in Engineering Software, Vol. 32, pp. 317-325 (2001). 